УДК 378:338.48

UDC 378:338.48

DOI: 10.31475/ped.dys.2019.27.05

ІРИНА ЗІНЬКОВА,

провідний фбахівець

(Украӥна, Івано-Франківськ, Навчально-науковий центр «Педагогіка і психологія вищої школи» Інституту вищої освіти НАПН України, ДВНЗ «Прикарпатський національний університет імені Василя Стефбаника», вул. Степана Бандери, 1)

IRYNA ZINKOVA, Leading Specialist

(Ukraine, Ivano-Frankivsk, Educational and Scientific Center "Pedagogy and Psychology of Higher School» of Institute of Higher Education of National Academy of Pedagogical Sciences of Ukraine, Vasyl Stefanyk Precarpathian National University

Stepan Bandera str., 1)

ORCID: 0000-0002-9916-7630

\title{
Формування професійно значущих особистісних якостей майбутніх фахівців сфери послуг і туризму засобами самоменеджменту
}

\section{Formation of Professionally Significant Personal Qualities of Future Specialists in the Sphere of Services and Tourism by Means of Self-Management}

У статті представлено наукове обтрунтування особливостей фборлування профбесійно значущих якостей майбутніх фбахівців сфбери послуг $i$ туризму. На підставі теоретикометодичних досліджень проведено аналіз результатів наукових розвідок, наведено розуління ключових категорій. До профбесійно значущих якостей віднесено колунікативність, інноваційність, креативність, клієнтоорієнтованість, ініціативність, готовність до ризику, організаційні здібності.

У статті висвітлено особливості ознайомлення майбутніх фбахівців сфбери послуг і туризму з уловали і чинниками підвищення ефбективності управління собою відповідно до встановлених функиій самоменеджменту, як-от: правильність визначення особистих иілей, планування діяльності, технології організації діяльності, салоконтроль $i$ фборлулювання висновків, ефбективне використання часу, здатність до управління стресами тощо. Здобувачі освіти були ознайоллені з теоретичними основали й засвойли практичні навички салоленеджленту.

Ключові слова: профбесійно значущі якості, сфбера послуг і туризму, саломенеджмент.

In the article the scientific substantiation of peculiarities of formation of professionally significant qualities of the future specialists in the sphere of services and tourism has been covered. On the basis of theoretical and methodological studies the results of scientific researchers, the understanding of the key categories, such as "professionally important qualities" and so on have been analyzed. Such qualities include communicativeness, innovation, creativity, client orientation, initiative, risk-taking, organizational skills.

The formation of professionally significant qualities has been accomplished in the educational process during the forming experiment on the problem of forming the entrepreneurial culture of students studying in the specialties 242 - "Tourism" and 241 - "Hotel and Restaurant Business". The tasks have been solved by introducing a special course "Entrepreneurial Culture of Specialist Services and Tourism: Theory and Practice", using self-management tools and supplementing the content of the program of different types of practices.

The article highlights the peculiarities of familiarizing students with the conditions and factors of improving self-management in accordance with the established functions of self-management, such as: correct definition of personal goals, planning activities, technology organization activities, self-control and formulation of conclusions, effective use of time, ability to manage stress, etc. Forms, methods and techniques of students' self-management skills during higher education have been presented, namely: group work, brainstorming, project technology, introspection. In this way, students were introduced to the theoretical basics and learned practical self-management skills.

Key words: professionally significant qualities, services and tourism, self-management.

Вступ / Introduction. Стрімкі темпи розвитку суспільства зумовлюють оновлення вимог до професійної підготовки фахівців для різних галузей господарства і тих якостей, якими вони мають 
володіти. Успіх професійного становлення особистості в сучасному світі забезпечують такі їі риси як активність, креативність, стресостійкість, критичне мислення, здатність до самоосвіти упродовж життя. У «Національній стратегії розвитку освіти в Україні на період до 2021 р.» 3 цього приводу зазначено, що одна з цілей програми зоріентована на особистісний розвиток людини відповідно до іï індивідуальних здібностей та потреб на основі навчання упродовж життя. Провідними засадами оновлення цілей і змісту освіти, як зазначено у документі, е компетентнісний та особистісно орієнтований підхід, урахування світового досвіду та принципів сталого розвитку (Національна стратегія розвитку освіти в Україні..., 2013).

Відповідно i стратегія професійної підготовки має орієнтуватися на фрормування конкурентоспроможного фахівця, здатного до постійного саморозвитку, професійної й особистісної самореалізації в сучасних умовах. При цьому необхідно спиратися на специфічні особливості майбутньої професійної діяльності.

Сфера послуг i туризму в сучасному суспільстві активно розвиваеться, оновлюеться, модернізуеться, оскільки зростають потреби споживачів і збільшуеться конкуренція в цьому сегменті економіки. Відповідно професійна підготовка фрахівців сфери послуг і туризму потребуе нових підходів та удосконалення.

Результати аналізу наукових джерел засвідчили, що проблема інноваційних підходів до системи професійної підготовки загалом знайшла відображення в працях Т.Андрущенка, І.Зязюна, В.Кременя, О.Падалка та ін. Низка дослідників розробляе методологічні засади й основоположні принципи професійної підготовки майбутніх фрахівців туристичної індустрії та сфери обслуговування (А.Віндюк, Л.Кнодель, Т.Сокол, М.Ткаченка, В.Федорченка, Н.Фоменко, І.Шпичко, Г.Щуки та інших), психологічні, педагогічні та методичні аспекти формування професійно значущих якостей майбутніх фахівців у контексті їх професійної компетентності досліджують І.Зорін, А.Казьмерчук, Л.Карамушка, М.Лобура, Г.Лоїк, Ю.Лозовюк, О.Приймук та ін.

Попри значну кількість наукових досліджень, присвячених порушеній проблемі, потребують уточнення шляхи формування професійно важливих якостей майбутніх фахівців сфери послуг i туризму, конкретизація відповідних фрорм i методів навчання, використання актуальних інноваційних підходів до вирішення проблеми. Доцільним вважаємо впровадження спеціального курсу «Підприемницька культура у сыері послуг і туризму: теорія i практика», а також використання в процесі професійної підготовки студентів галузі «Сфера обслуговування» засобів самоменеджменту, які зоріентовані на особистісне становлення майбутнього професіонала.

Мета та завдання / Aim and Tasks. Метою статті е виокремлення ефрективних шляхів формування професійно значущих якостей майбутніх фахівців сфери послуг і туризму в освітньому процесі ЗВО засобами самоменеджменту. Основні завдання: виокремити професійно значущі якості фахівців сфери послуг і туризму, схарактеризувати найбільш ефективні шляхи формування таких якостей в процесі професійної підготовки фрахівців означеної галузі засобами самоменеджменту.

Методи / Methods. Для досягнення мети дослідження й вирішення поставлених завдань було використано низку методів наукового пошуку, а саме: аналіз і узагальнення науково-методичної літератури, систематизація результатів опитування респондентів щодо переліку професійно значущих якостей фахівців у контексті їх підприемницької культури, моделювання методики формування професійно значущих якостей майбутніх фахівців сфери послуг і туризму в освітньому процесі ЗВО з використанням засобів самоменеджменту.

Результати / Results. У сучасній науковій літературі використовуються поняття «професійно значущі якості», «професійно важливі якості», «професійні якості» та інші синонімічні категорії. Розглянемо деякі підходи учених до вирішення порушеної проблеми. Дослідження сутності професійно значущих якостей здійснюють Є.Єрмолаєва, Є.Клімов, М.Лобур, А.Маркова, О.Приймук, В.Шадриков та інші науковці. М.Лобур використовуе поняття «професійно значущі якості» i розуміе їх як «особисті якості суб’екта, які необхідні для успішного оволодіння профресійними знаннями, вміннями i навичками, вони визначають успішність навчання у встановлені терміни і ефективність професійної діяльності» (Лобур М., 2006).

У дисертаційній роботі О.Приймук використовуе категорію «професійно важливі якості» й досліджуе психологічні засади формування таких якостей в процесі професійної підготовки майбутніх фахівців ресторанної справи. Авторка обгрунтовуе інтегральний підхід до вирішення проблеми i спираеться на структурні компоненти особистості, а саме: комунікативний, мотиваційний, професійного спрямування, емоційно-вольовий та індивідуально-психологічний компонент (Приймук О., 2017). А успіх професійного становлення, на думку дослідниці залежить від низки характеристик, як-от:

- професійна мотивація - активність особистості, спрямована на задоволення як біологічних потреб, так і потреб приналежності до професійної спільноти, міжособистісного спілкування, 
самореалізації;

- загальна i професійна підготовленість - сукупність компетентностей, необхідних для вирішення профресійних завдань;

- рівень фрункціональної готовності організму до профресійної діяльності, відповідний розвиток аналізаторів, фрізичних якостей тощо;

- стан індивідуально-психологічних фрункцій людини (психомоторика, темпераментальні, характерологічні й емоційно-вольові характеристики особистості) (Приймук О., 2017).

Отож, професійна діяльність в будь-якій галузі грунтуеться на сукупності відповідних якостей, які обумовлюються специфікою ціеї діяльності й формуються на різних етапах становлення професіонала. Базові якості особистості, необхідні для виконання професійних фрункцій, охоплюють різні сторони відповідної професії (технологічні, психологічні, соціальні, економічні, технічні тощо) й представлені у продесіограмі.

Зміст професійної підготовки в закладі вищої освіти також має базуватися на вимогах профресіограми з урахуванням перспектив розвитку галузі. У контексті порушеної проблеми, це професіограми фрахівців сфери послуг і туризму, а саме адміністратори, менеджери, фрахівці 3 гостинності, туризмознавці, екскурсоводи, організатори подорожей та інші. Оскільки діяльність фрахівців перелічених професій зосереджена в туристичній індустрії, готельно-ресторанному господарстві, то і професійно значущі якості, які необхідно сформувати у майбутніх фрахівців сфери обслуговування в багатьох аспектах будуть співзвучними. Розглянемо наукові підходи до порушеної проблеми.

О.Приймук зазначає, що сучасна підготовка фрахівців готельно-ресторанної справи акцентує увагу на «якості освіти, формуванні професійних компетентностей, здатності розуміти інших людей, уміння співпрацювати, взаємодіяти, комунікувати, керувати персоналом і створювати атмосферу довіри, вміло формулювати цілі й добирати методи їх досягнення, а також своєчасно реагувати на запити ринку» (Приймук О., 2017). Модель фахівця туризму та готельної справи розробив В.Зінченко і класифікуе ї складові на дві групи особистісних якостей, а саме: узагальнені, які є важливими для випускників будь-яких навчальних закладів та спеціальні властиві спеціалісту конкретної профресії та відповідного освітнього рівня (Зінченко В., 2017$).$ Особистісну компетентність учений розглядае як сукупність аксіологічної, персональної, інформаційної, екологічної та валеологічної складових, а профресійна (у сфері послуг і туризму) містить соціальну, комунікативну, організаційну, пошуково-реконструктивну, анімаційну, аутокомпетентність. До профресійно важливих якостей В.Зінченко відносить «пам'ять, творче мислення, організованість, зібраність, акуратність, пунктуальність, емоційну стійкість, допитливість, спостережливість, уважність, відкритість, контактність. Загальні психофізіологічні властивості представлені редлексивністю, гнучкістю, абстрагуванням, а спеціальні - вербалізація, емоційна стабільність» (Зінченко В., 2017).

На зміст профресійно значущих якостей фахівців різних галузей впливає також суспільний прогрес, соціально-економічна ситуація в країні, оновлення запитів роботодавців і потреб споживачів тощо. Задля визначення найбільш затребуваних якостей працівників було проведено опитування менеджерів та працівників туристичних агенцій, керівників і адміністраторів готелів і ресторанів приватної форми власності, проаналізовано посадові інструкції працівників. Респонденти ранжували перелік особистісних якостей у порядку від найбільш профресійно значущих до найменш важливих у змісті підприємницької культури фрахівця. Перелік якостей укладали з опертям на результати наукових психолого-педагогічних розвідок та аналізу посадових інструкцій фрахівців сфери послуг і туризму. До таких якостей було віднесено: рішучість, ініціативність, організаторські здібності, креативність, відкритість, уважність, комунікативність, клієнтоорієнтованість, енергійність, емпатія, самокритичність, готовність до ризику, гнучкість, стресостійкість, оптимізм. Також респонденти могли запропонувати ті якості, які вважають важливими, але в даному переліку не представлені. Загалом до опитування було залучено 86 осіб (керівників і працівників закладів готельно-ресторанного бізнесу та туристичної галузі міст ІваноФранківськ, Чернівці, Львів). Аналіз одержаних результатів засвідчив, що найбільш затребуваними є фрахівці з такими якостями як комунікативність (38,9 \%), клієнтоорієнтованість $(25,1 \%)$, ініціативність $(12,3 \%)$ і т.д. Серед якостей, яких не було представлено в переліку найбільш поширеними були відповідальність (2,3 \%), незалежність (1,1\%), прагматичність (0,8 \%). Таким чином вдалося 3'ясувати, що виокремлені дослідниками якості частково збігаються 3 найбільш значущими для сучасних роботодавців.

Узагальнення й систематизація результатів наведених розвідок, дотичних до проблеми наукових праць та результати опитування керівників та працівників підприемств сфери послуг i туризму приватної форми власності 3 різним трудовим стажем засвідчив, що найбільш затребуваними особистісними якостями для успішної діяльності фрахівця у сучасній сфері послуг i 
туризму е інноваційність, комунікативність, креативність, кліентооріентованість, ініціативність, готовність до ризику, організаційні здібності тощо. Перелічені якості розглядаємо у контексті формування підприемницької культури фахівців означеної галузі.

Як відомо, професійно важливі якості формуються упродовж різних етапів професійного становлення особистості, як-от: вибору професії, професійної підготовки, професійної адаптації, професіоналізації. Значний потенціал для цілеспрямованого формування таких якостей має процес професійної підготовки, який базуеться на відповідних стандартах, нормативно-правовій базі, враховуе сучасні реалії розвитку відповідної галузі. Перелічені якості формували у студентів ДВНЗ «Прикарпатський національний університет імені Василя Стефаника", які навчаються за спеціальностями 242 - «Туризм» і 241 - «Готельно-ресторанна справа».

У процесі розв’язання порушеної проблеми було сформульовано такі завдання:

- поглиблення знань студентів про специфіку підприемницької діяльності у туристичній галузі та готельно-ресторанному господарстві;

- ознайомлення із соціокультурним, організаційним i особистісно-діяльнісним вимірами підприемницької культури;

- формування у майбутніх фахівців відповідних компетентностей, умінь і навичок в процесі аудиторної, позааудиторної діяльності та під час проходження різних видів практик.

Вирішення поставлених завдань здійснювали шляхом використання контекстного підходу під час вивчення дисциплін циклів загальної та професійної підготовки, впровадження спеціального курсу «Підприемницька культура фахівця сфери послуг i туризму: теорія i практика», використання засобів самоменеджменту та доповнення змісту програми різного виду практик. Розглянемо особливості використання засобів самоменеджменту у процесі формування професійно значущих якостей майбутніх фахівців сфери послуг і туризму, оскільки завдяки самоменеджменту особистість має змогу проаналізувати власні якості, схильності, можливості, бажання, узгодити їх з потребами, оптимально зорганізувати професійну діяльність і продовжувати самовдосконалення. 3 категоріями самоменеджменту студенти ознайомлювалися під час вивчення авторського спецкурсу, оскільки в межах професійного модуля було передбачено опрацювання теми «Самоменеджмент фахівців сфери послуг і туризму».

Як відомо, поняття «самоменеджмент» уперше використав Л.Зайверт і трактував його 3 акцентом на економію часу. Учений вважав, що сутність цієї категорії полягае в послідовному і цілеспрямованому використанні надійних методів свідомого використання людиною часу для оптимальної організації щоденної діяльності. Однак, у сучасних наукових розвідках розуміння поняття самоменеджменту значно ширше, оскільки передбачае як оптимальне використання часу, так і постановку професійних та особистісних цілей, організацію професійної діяльності та успішної співпраці з колегами.

О.Крикун визначає самоменеджмент як науку про самоуправління i самоорганізацію особистості, управління його ресурсами, тобто уміння розвивати, зберігати, раціонально використовувати свій час і при цьому бути успішною людиною (Крикун О., 2014).

Під час вивчення спеціального курсу ознайомили студентів 3 теоретичними засадами самоменеджменту (сутність, підходи до розуміння, напрями, функціональне призначення тощо) та можливостями їх практичного застосування. Дослідники виокремлюють декілька напрямів такого саморозвитку, а саме: особистісне зростання, інтелектуальний розвиток, професійне становлення, підтримка фізичного стану (Крикун О., 2014).

Стан розвитку професійно значущих якостей студентів визначали до допомогою опитування, психологічних тестувань, психолого-педагогічного спостереження й ознайомлення студентів 3 одержаними результатами. Удосконалення наведених якостей здійснювали з урахуванням індивідуальних особливостей, потреб, бажань, мотивів. А під час занять, проходження виробничої практики тощо було визначено, наскільки ці якості сприяють досягненню успіху чи, навпаки, заважають професійній та особистісній самореалізації. Студентів ознайомлювали з умовами i чинниками підвищення ефективності управління собою відповідно до встановлених функцій самоменеджменту, як-от: правильність визначення особистих цілей, планування діяльності, технології організації діяльності, самоконтроль i формулювання висновків, ефективне використання часу, здатність до управління стресами тощо.

Для формування умінь правильно визначати особисті цілі майбутніх фахівців сфери послуг і туризму стимулювали до чіткого усвідомлення поняття «успіх», а також ознайомили 3 технікою SMART (ціль повинна бути конкретною, вимірюваною, в межах досяжності, прагматичною, визначеною в часі).

Для ефективного планування діяльності пропонували дотримуватися певних правил, а саме: реалістичність обсягів роботи, визначення резерву часу, дотримуватися регулярності й системності в процесі планування, фокусування на результатах, а не на діях. Відповідно до ідей 
М.Орликовського технологія планування має містити низку етапів, як-от: 1) перелік видів діяльності, які потрібно виконати у планованому періоді; 2) визначення витрат часу на виконання окремих операцій; 3) визначення резерву часу; 4) формування фонду робочого часу планованого періоду; 5) контроль - якщо часу не вистачае, переглянути перелік окремих видів діяльності; 6) складання плану; 7) внесення змін під час реалізації (Орликовський М., 2012).

Однією з основних функцій самоменеджменту вважають організацію діяльності. Засвоєння студентами технік організації діяльності відбувалося з використанням інтерактивних методів i, зокрема, «мозкового штурму». Робота проводилася в групах, кожна з яких розглядала окрему техніку, представляючи ії сильні і слабкі сторони, аргументуючи думку прикладами, окреслюючи перспективи використання в туристичній індустрії або готельно-ресторанному бізнесі. Таким чином були розглянуті принцип Парето, АВС-аналіз, принцип Ейзенхауера та інші методики. Психологічні вимоги до самоконтролю, процедури його здійснення та можливі перешкоди студенти самостійно формулювали в процесі групової роботи й представляли для загального обговорення.

Самостійна робота студентів передбачала аналіз сучасної популярної літератури 3 питань самоменеджменту, тайм-менеджменту, саморозвитку, самомотивації. Така література набуває все більшої популярності, написана доступною мовою, актуальна для людей різного віку і дуже часто мотивуе особистість до самовдосконалення. Завдання студентів полягало в створенні картотеки 3 питань самоменеджменту й представлення однієї з книг у вигляді есе, буктрейлера чи презентації, виконаної за допомогою програми PowerPoint.

Підсумком вивчення теми студентам було запропоновано проаналізувати власний стан розвитку професійно значущих якостей (ініціативність, клієнтоорієнтованість, ініціативність, комунікативність, організаторські здібності тощо) і розробити план саморозвитку з використанням вивчених технік та методів.

Таким чином студентів було ознайомлено з методиками, техніками, стратегіями самоменеджменту, які доцільно використовувати для постановки особистісних і професійних цілей, планування, організації і контролю діяльності, як навчальної, так і в майбутньому професійної.

Обговорення / Discussion. Питання використання можливостей самоменеджменту в процесі професійної підготовки майбутніх фахівців різних галузей представлено в роботах О.Крикуна, М.Лукашевич, М.Матішак, М.Орликовського, Г.Осовської, Л.Пермінової, Х.Плецан, Б.Ренькаса, Г.Ткачук, О.Цимбал, О.Штепи та інших дослідників. Більшість дослідників наголошують на актуальності проблеми формування навичок самоменеджменту в студентів й пропонують власні підходи до ї̈ вирішення.

О.Цимбал аналізуе провідні моделі компетенцій світових стандартів (SHL, S. Whiddett \& S. Hoolyforde, Society for Human Resource Management) і вважае, що майбутній менеджер освіти повинен володіти теоретичними знаннями і практичними навичками з планування та організації власної роботи. Погоджуємося з авторкою у тому, що ознайомлення з теорією самоменеджменту під час магістерської підготовки додає майбутнім менеджерам управлінських знань, умінь i відповідних навичок, а також допомагає оптимально формулювати цілі свого індивідуального розвитку. Водночас О.Цимбал пропонуе ввести навчальну дисципліну «Самоменеджмент» до складу комплексу нормативних дисциплін в освітньо-професійну програму підготовки магістрів різних спеціальностей (Цимбал О., 2016). За результатами наукових розвідок М.Матішак (Матішак М., 2016), навички самоменеджменту студентів доцільно формувати також на етапі бакалаврської підготовки, оскільки постановка цілей, планування, організація діяльності, контроль е актуальними і в освітній діяльності студентів, і під час їх майбутньої профресійної самореалізації. Л.Пермінова виокремлюе психолого-педагогічні умови, які сприяють ефективності проектної діяльності студентів й передбачають розвиток навичок самоменеджменту, як-от: усвідомлення студентами цілей, характеру і результатів діяльності; обговорення способів роботи, рольового розподілу, правил роботи в групі; право коректувати діяльність в процесі роботи тощо (Пермінова Л., 2017).

Беручи до уваги результати вище наведених досліджень та практичне значення проблеми нами запропоновано власний підхід до ознайомлення студентів галузі 24 «Сфера обслуговування» iз засобами самоменеджменту інтегруючи практичний і діяльнісний аспект, використовуючи інтерактивні методи навчання та групову форму організації пізнавальної діяльності на рівні бакалаврської підготовки.

Ефективність використання засобів самоменеджменту в процесі формування професійно значущих якостей зумовлена тим, що студенти вчаться виявляти власні особистісні якості, можливості, бажання, прагнення, максимально використовувати ресурси, свідомо управляти часом, емоціями, долати перешкоди та зовнішні обставини.

У виконаному дослідженні наведено послідовність формування професійно значущих якостей у відповідності 3 функкціями самоменеджменту, які $є$ одними 3 ключових понять порушеної 
проблеми. Позитивним аспектом вважаємо ознайомлення студентів з методиками та технологіями самоменеджменту, спрямованими на оптимізацію постановки особистісних і професійних цілей, планування, організацію i контроль діяльності. Перелічені методики і технології самоменеджменту студенти можуть застосовувати під час навчальної та самоосвітньої діяльності, а в майбутньому як для особистісного розвитку, так і для оптимізації професійної діяльності й самореалізації загалом.

Висновки / Conclusions. Отже, використання засобів самоменеджменту в закладі вищої освіти забезпечуе успішне формування професійно значущих якостей майбутніх фахівців сфери послуг і туризму. Водночас, сформованість навичок самоменеджменту впливає на загальну ефективність особистості, оскільки забезпечуе усвідомлене формулювання цілей, оптимальний розподіл часу, особистісних ресурсів, здатність подолання стресових ситуацій, емоційну саморегуляцію.

Перспективи подальших наукових розвідок вбачаємо у виокремленні найбільш ефективних шляхів ознайомлення здобувачів вищої освіти за напрямом 24 «Сфера обслуговування» 3 особливостями самомаркетингу, а також опанування ними стратегії і тактики побудови ділової кар'ери, що сприяе посиленню конкурентоздатності в умовах ринкової економіки.

\section{Список використаних джерел і літератури:}

Гаврилюк А. М., \& Плецан, Х. В. (2016). Тайм-менеджмент як складова успішної комунікативної взаемодії в індустрії туризму України. Ефбективна еконоліка, $1 . \quad$ Взято 3 http://nbuv.gov.ua/UJRN/efek_2016_1_9 [in Ukrainian].

Зінченко, В. А. (2017). Особливості підготовки кадрів туризлу $i$ готельної справи в уловах євроінтеграцї України та підвищення конкурентності туристичної галузі. Взято 3 http://chteiknteu.cv.ua/herald/content/download/archive/2017/v3/NV-2017-v3 24.pdf / [in Ukrainian].

Крикун, О. А. (2014). Самоленеджмент. Харьков: ХНУ имени В. Н. Каразина [in Russian].

Лобур, М. С. (2006). Форлування професійно значущих якостей майбутніх молодших фбахівиів сфбери харчування. (Дис. канд. пед. наук). Київ [in Ukrainian].

Матішак, М. (2016). Формування навичок самоменеджменту майбутніх вихователів ДНЗ. Освітній простір України, 14, 88-92 [in Ukrainian].

Національна стратегія розвитку освіти в Україні на період до 2021 р. (2013). Взято 3 https://zakon3.rada.gov.ua/laws/show/344/2013/ [in Ukrainian].

Орликовський, М. О., Осовська, Г. В., \& Ткачук, В. I. (2012). Салоленеджлент. Практикул: терліни, тести, практичні завдання та ситуації. Київ: Кондор [in Ukrainian].

Пермінова, Л. А. (2017). Засоби бборлування навичок самоменеджменту майбутнього педагога. Взято з http://ps.stateuniversity.ks.ua/file/issue_65/83.pdf/[in Ukrainian].

Приймук, О. О. (2017). Психологічні умови бборлування профбесійних якостей здобувачів вищої освіти (Дис. канд. психол. наук). Київський національний торговельно-економічний університет. Kиїв [in Ukrainian].

Цимбал, О .Ю. (2016). Самоменеджмент в структурі профбесійної підготовки майбутнього керівника навчального закладу. Взято з http://molodyvcheny.in.ua/files/journal/2016/6/119.pdf / [in Ukrainian].

\section{References:}

Havryliuk, A. M., \& Pletsan, Kh .V. (2016). Taim-menedzhment yak skladova uspishnoi komunikatyvnoi vzaiemodii v industrii turyzmu Ukrainy [Time-Management as Part of Successful Communicative Interaction the Tourism Industry in Ukraine]. Efektyuna ekonomika - Effective Economic, 1 . Retrieved from http://nbuv.gov.ua/UJRN/efek_2016_1_9 [in Ukrainian].

Zinchenko, V. A. (2017). Osoblyvosti pidhotovky kadriv turyzmu i hotelnoi spravy $v$ umovakh yevrointehratsii Ukrainy ta pidvyshchennia konkurentnosti turystychnoi haluzi [Features of Training Employeees of Tourism and Hotel Business in Ukraine under the Conditions of Eurointegration and Increasing Competitiveness of the Tourism Sector]. Retrieved from http://chtei-knteu.cv.ua/herald/content/download/archive/2017/v3/NV-2017-v3_24.pdf [in Ukrainian].

Krykun, O. A. (2014). Samomenedzhment [Self-Management]. Kharkov: KhNU imeni V. N. Karazina [in Russian]

Lobur, M. S. (2006). Formuvannia profesiino znachushchykh yakostei maibutnikh molodshykh fakhivtsiv sfery kharchuvannia [The Formation of Professional Qualities of Future Junior Specialists of the Nutrition]. (Candidate's thesis). Kyiv [in Ukrainian].

Matishak, M. (2016). Formuvannia navychok samomenedzhmentu maibutnikh vykhovateliv DNZ [Formation of Skills of Self-Management of Future Kindergarten Educators]. Osvitnii prostir Ukrainy - The Educational Space of Ukraine, 14, 88-92 [in Ukrainian].

Natsionalnia stratehiia rozvytku osvity $v$ Ukraini na period do $2021 \mathrm{r}$. [National Strategy for the Development of Education in Ukraine until 2021]. (2013). Retrieved from https://zakon3.rada.gov.ua/laws/show/344/2013 [in Ukrainian].

Orlykovskyi, M. O., Osovska, H. V., \& Tkachuk, V. I. (2012). Samomenedzhment. Praktykum: terminy, testy, praktychni zavdannia ta sytuatsii. [Self-Management. Workshop: Terms, Tests, Practical Tasks and Situations]. Kyiv: Kondor [in Ukrainian].

Perminova, L. A. (2017). Zasoby formuvannia navychok samomenedzhmentu maibutnoho pedahoha [Self- 
Management Methods of Skills Forming of the Future Pedagogue]. Retrieved from http://ps.stateuniversity.ks.ua/file/issue_65/83.pdf [in Ukrainian].

Pryimuk, O. O. (2017). Psykholohichni umovy formuvannia profesiinykh yakostei zdobuvachiv vyshchoi osvity [Psychological Conditions for the Formation of Professional Qualities of Higher Education Graduates]. (Candidate's thesis). Kyiv [in Ukrainian].

Tsymbal, O. Yu. (2016). Samomenedzhment $v$ strukturi profesiinoi pidhotovky maibutnoho kerivnyka navchalnoho zakladu [Self-Management in the Structure of Professional Training of the Future Manager of Educational Institution]. Retrieved from http://molodyvcheny.in.ua/files/journal/2016/6/119.pdf [in Ukrainian].

Дата надходження статті: «30» вересня 2019 р.

Стаття прийнята до друку: «22» жовтня 2019 р.

Зінькова Ірина - провідний фрахівець Навчально-наукового центру «Педагогіка і психологія вищої школи» Інституту вищої освіти НАПН України та ДВНЗ «Прикарпатський національний університет імені Василя Стефаника»

Zinkova Iryna - Leading Specialist of Educational and Scientific Center «Pedagogy and Psychology of Higher School» of Institute of Higher Education of National Academy of Pedagogical Sciences of Ukraine, Vasyl Stefanyk Precarpathian National University

\section{Цитуйте цю статтю як:}

Зінькова, I. (2019). Формування професійно значущих особистісних якостей майбутніх фахівців сфери послуг і туризму засобами самоменеджменту. Педагогічний дискурс, 27 doi: 10.31475/ped.dys.2019.27.05.
Cite this article as:

Zinkova, I. (2019). Formation of Professionally Significant Personal Qualities of Future Specialists in the Sphere of Services and Tourism by Means of SelfManagement. Pedagogical Discourse, 27, 43-49. doi: 10.31475/ped.dys.2019.27.05. 